\title{
Study of Different Construction Processes Affecting the Installation of Appropriate Cambers for Long-Span Railway Cable-Stayed Bridges
}

\author{
Chen Zengshun ${ }^{1}$, Song Jun ${ }^{1}$, Zhang Cheng ${ }^{1}$, Huang Guanrong ${ }^{2} \&$ Wei Haoyang ${ }^{1}$ \\ ${ }^{1}$ School of Civil Engineering \& Architecture, Chongqing Jiaotong University, Chongqing, China \\ ${ }^{2}$ School of Foreign Language, Chongqing Jiaotong University, Chongqing, China \\ Correspondence: Chen Zengshun, School of Civil Engineering \& Architecture, Chongqing Jiaotong University, \\ Chongqing 400074, China. E-mail: chenzs2007@163.com
}

Received: May 3, 2013 Accepted: July 11, $2013 \quad$ Online Published: July 25, 2013

doi:10.5539/mas.v7n8p89 URL: http://dx.doi.org/10.5539/mas.v7n8p89

\begin{abstract}
There are few studies on the installation of appropriate cambers for long-span railway cable-stayed bridges at home and abroad. This article describes the influential factors of thte installation of cambers, and analyses its theories and approaches, as well as takes use of design formula for appropriate camber installation. Combining project cases of long-span railway cable-stayed bridges, and exploiting FEM software-Midas civil2010, the article has an analytic study on effects of different construction processes on camber installation, which is the basis of installing cambers of such bridges in the future.
\end{abstract}

Keywords: long-span railway cable-stayed bridges, appropriate cambers, construction processes

\section{Introduction}

As long-span railway cable-stayed bridges, alignment control within the process of construction is quite complex, including: structural coefficient, shrinkage and creep of materials. Besides, different construct processes have a significant impact on alignment control (Ding, Lu, Meng, \& Liu, 2004; Ge, 2003; Xu, 2000). Installation of appropriate camber is prior to any other factor, which if inappropriate, the quality and lifespan of bridges will be decreased, even the two sections of a bridge cannot be joined. At present, few studies have been done on on different construction processes affecting the installation of appropriate cambers for such bridges (Housner et al., 1999; Curran \& Tilly, 1999). In combination with theories and engineering practices, this article studies of the importance of different construction processes affecting alignment control for long-span railway cable-stayed bridges, which is the basis of installing cambers of such bridges in the future.

\section{Theories and Calculating Methods of Camber Installation in the Process of Construction}

Camber installation for long-span railway cable-stayed bridges can be classified into two categories, namely, cambers during construction and cambers after bridges being built, which are two factors influencing cambers. The purpose of cambers during construction is to offset effects on alignment produced by shrinkage, creep of concrete, as well as live load. Synthesizing these two kinds of camber installation, Table 1 summarizes influential factors of camber installation for long-span railway cable-stayed bridges, just as follows ( $\mathrm{Li}, 2010$; Liang, 2006; Zhang, 2004): 
Table 1. Influential factors of appropriate cambers installation for long-span railway cable-stayed bridges

\begin{tabular}{|c|c|c|c|}
\hline Camber & Influential factors & $\begin{array}{l}\text { Direction of camber } \\
\text { installation }\end{array}$ & Method of camber installation \\
\hline \multirow{8}{*}{$\begin{array}{l}\text { Camber during } \\
\text { construction }\end{array}$} & Weight of structures & Upward & \multirow{8}{*}{$\begin{array}{c}\text { Sequential analysis, simulation of } \\
\text { construction processes, as well as } \\
\text { piecewise overlay analysis }\end{array}$} \\
\hline & Pre-stress & Downward & \\
\hline & Initial tension of stays & upward/downward & \\
\hline & Secondary dead load & upward & \\
\hline & $\begin{array}{c}\text { Shrinkage and creep in } \\
\text { early period }\end{array}$ & upward/downward & \\
\hline & Temporary & & \\
\hline & $\begin{array}{l}\text { load(moving baskets, } \\
\text { wet weight) }\end{array}$ & upward & \\
\hline & $\begin{array}{l}\text { Other } \\
\text { factors(temperature, } \\
\text { deformation of piers) }\end{array}$ & upward/downward & \\
\hline \multirow{2}{*}{$\begin{array}{l}\text { Camber after } \\
\text { bridges being } \\
\text { built }\end{array}$} & $\begin{array}{c}\text { Shrinkage and creep in } \\
\text { later period }\end{array}$ & upward/downward & \multirow{2}{*}{$\begin{array}{l}\text { Analytic method combining } \\
\text { formula and empirical method }\end{array}$} \\
\hline & $1 / 2$ live load & upward & \\
\hline
\end{tabular}

\subsection{Influential Factors of Camber Installation for Long-Span Railway Cable-Stayed Bridges}

In the process of construction for long-span railway cable-stayed bridges, installation of cambers is affected by a variety of factors, including: weight of concrete, pre-stress, force produced by stays, deformation of moving the hanging basket, shrinkage and creep in the process of construction, secondary dead load (Tan \& Zhang, 2008; Fan \& Du,1992; Xiao,1992).

1) The following formula which can be used to calculate the effect on camber installation caused by concrete weight (Li, 2010; Liang, 2006; Zhang, 2004).

$$
\left[\begin{array}{ccccc}
\delta_{11} & \delta_{12} & \delta_{13} & \cdots & \delta_{1 n} \\
0 & \delta_{22} & \delta_{23} & \cdots & \delta_{2 n} \\
0 & 0 & \delta_{33} & \cdots & \delta_{3 n} \\
0 & 0 & 0 & \cdots & \delta_{4 n} \\
0 & 0 & 0 & 0 & \delta_{n n}
\end{array}\right]\left[\begin{array}{c}
1 \\
1 \\
1 \\
1 \\
1
\end{array}\right]=\left[\begin{array}{c}
\Delta_{1} \\
\Delta_{2} \\
\Delta_{3} \\
\cdots \\
\Delta_{n}
\end{array}\right]
$$

In the formula, $\delta_{i j}$ denotes the deformation value which phrase $\mathrm{j}$ applies on phrase $\mathrm{i}$ and $\Delta_{i}$ denotes deformation value of accumulative weight in section $i$.

2) Analysis about the effect of pre-stressing force (Li, 2010; Liang, 2006; Zhang, 2004).

Assuming that effective pre-stress forces through a cross-section are $F_{1}, F_{2}, F_{3} \cdots F_{n}$, the distance between pre-stress and neutral axis is $h_{1}, h_{2}, h_{3} \cdots h_{n}$. According to structural mechanics, bending moment acting on differential element $\mathrm{d}(\mathrm{x})$ is:

$$
M(x)=\sum_{i=1}^{n} F_{i} h_{i}
$$

Thus the deflection value of pre-stress acting on differential element $\mathrm{d}(\mathrm{x})$ is:

$$
f=\int \frac{M(x)+\overline{M(x)}}{E(x) I(x)} d(x)
$$

3) Analysis about the effect of initial tension.

While being tensioned, stay-cables will produce a group of inclined upward forces on segments, which, under initial tension, will produce upward deflection whose value can be calculated through structural mechanics. And then reverse the value when installing cambers. 
4) Analysis about the effect of secondary dead load

Under secondary dead load, main girder can produce downward deflection, which load on beam elements can simulate. After calculating its deflection, we just reverse it when installing camber.

5) Analysis about shrinkage and creep in early period (Ding, Lu, Meng, \& Liu, 2004)

In practical situations, creep, shrinkage as well as temperature strain are not isolated while happen together. Generally speaking, temperature stress and strain should analyze singly while shrinkage and creep should be calculated together, which we can refer to standard specification of CEP-FIP (1990) and Specification for design of highway reinforced concrete and pre-stressed concrete bridges and culverts.

6) Analysis about the effect of temporary load during construction (moving hanging baskets, braces etc.)

Under combined action of weight of moving hanging baskets, braces etc. and weight of segments, moving hanging baskets and braces will produce elastic deformation and none-plastic deformation, which can be calculated by tests. When installing camber, we should take these two parts into account.

7) Analysis about the effect of temperature

Temperature will inevitably affect the process of construction and displacement measurement. High temperature will result in error, so lower temperature and stabilized time period are better choices in practice. Additionally, to decrease the effect of temperature on camber installation, we can measure it repeatedly, then, know its law.

8) Analysis about construction load

Construction load will be removed in later period, which may result in compression of piers and deformation of moving hanging baskets etc.. We should eliminate such impact when installing camber.

\subsection{Theories and Calculating Methods of Camber After Bridges Being Built}

Camber installation after bridges being built is mainly affected by shrinkage and creep in later period as well as live load after being open to traffic. As for the complexity of the impact of shrinkage and creep on camber installation, we can get it by tests, experiences or theories and generally, combining FEM software-Midas civil2010 and experiences (curve distribution method etc.). The effect of live load on camber after bridges being built can be known by modeling method.

When installing cambers for long-span railway cable-stayed bridges, the above all factors should be taken into consideration. Based on results of deflection and recognizing parameters, actual modeling levels can be done after analyzing each influential factor of deflection correctly. As for the "gray part" of influential factors, if not being analyzes correctly, predicative analysis method should be taken, such as gray theory and linear regression method. Design formula of total camber can like this (Wang, Tang, \& Zheng, 2004; Xiao, 1996; Xiang, 2001):

$$
\begin{gathered}
f=f_{i}+f_{c} \\
f_{i}=\sum f_{1 i}+\sum f_{2 i}+f_{3 i}+f_{4 i}+f_{5 i}+f_{6 i}+f_{7 i}+f_{8 i} \\
f_{c}=\alpha d_{1}+\frac{1}{2} d_{2}
\end{gathered}
$$

In the formula:

$f_{i}$ - camber during construction

$f_{c}$ - camber after bridges being built

$\sum f_{1 i}$ - total deflection value after the segments finished and in later phrases

$\sum f_{2 i}$-impact value of longitudinal tension pre-stress during this phrase and next phrases

$f_{3 i}$-camber caused by weight of structures during construction

$f_{4 i}$-camber caused by pre-stressing load

$f_{5 i}$ - camber caused by initial tension of stay-cables

$f_{6 i}$-camber caused by secondary dead load

$f_{7 i}$-camber caused by shrinkage and creep during construction

$f_{8 i}$ - camber caused by temporary load during construction

$\alpha$-empirical coefficient

$d_{1}$ - deflection value affected by shrinkage and creep after bridges being built for 20 years 
$d_{2}$-deflection value of moving load

\section{Effects of Different Construction Processes on Alignment Control}

According to those factors of affecting camber installation for long-span railway cable-stayed bridges above-mentioned in the process of cantilever construction every construction phrase influences each other regardless of being independent that segments later done have an impact on segments previously built, and temporary load and construction load which are removed will affect camber installation. However, because of different situations in the process of construction, sequences of construction will change, and construction projects will change, which results in changing installation of camber.

For long-span railway cable-stayed construction, the construction of long-span railway cable-stayed bridge adopts cantilever pouring sequential construction, whose main construction processes are including (Xu, 2000; $\mathrm{Li}, 2010)$ :

1) Construction of Block 1;

2) Construction of segments in main girder by cantilever;

3) Cast-in-place construction and closure construction of side span;

4) Closure construction of central span;

5) Application of secondary load.

To treat of the effect of different construction processes on camber installation for long-span railway cable-stayed bridges, we just adjust construction processes of such bridges slightly, dividing into two situations:

1) According to main construction processes, weights of side span and central span are applied respectively, and moving baskets are then removed after segments in main girder finished;

2) Weights of side span and central span are applied together, and moving baskets are then removed after closure of central span.

Because of changes of construction phrases, these two ways of construction processes only have an impact on cambers during construction, not cambers after bridges being built (camber of shrinkage and creep, camber of live load). In addition, the impact on camber during construction is mainly accumulative construction part (consisting of temporary load during construction, weight of structures, secondary load, pre-stress, displacement caused by stay force).

\section{Case Study}

Main bridge of a long-span railway cable-stayed bridge is a dual-pylon-dual-plane concrete cable-stayed bridge, whose span is $60+135+250+135+60 \mathrm{~m}$. Its tower is a shape of diamond, and about $183 \mathrm{~m}$ in height, as well as its auxiliary piers are hollow with rectangular cross-section. There are totally 56 pairs of stays. Main beam adopts concrete box girder with single-box-single-cell and same height of girders, whose width is $15 \mathrm{~m}$, and height is $3.5 \mathrm{~m}$.

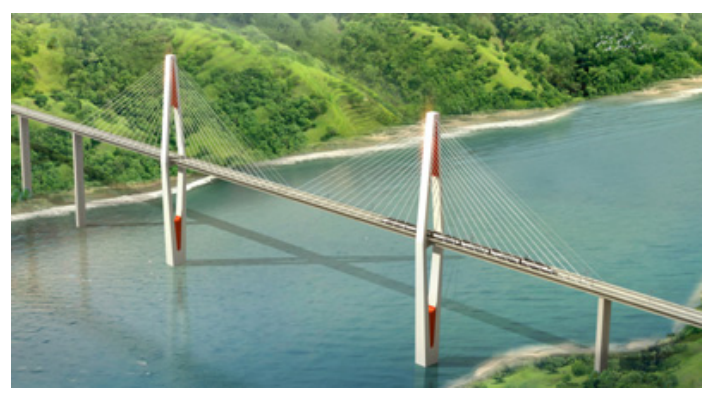

Figure 1. Effect drawing of a long-span railway cable-stayed bridge

During construction, the method of cantilever pouring sequential construction is often used, whose main construction processes are including:

1) Construction of Block 1;

2) Construction of segments in main girder from No.1 to No.15 by symmetric method of moving basket 
cantilever;

3) Cast-in-place construction and closure construction of side span;

4) Closure construction of central span;

5) Application of secondary load.

To treat of the impact of construction processes on cambers, according to the two ways of construction, slight changes are made, that is, weights of side span and central span are applied respectively, and moving hanging baskets are then removed after segments 15 finished, as well as Weights of side span and central span are applied together, and moving hanging baskets are then removed after closure of central span.

Now using FEM software-Midas civil2010, 819 nodes and 703 units are formed, which establishes the following model.



Figure 2. Midas model of a long-span railway cable-stayed bridge

(a) According to the first situation, that is, weights of side span and central span are applied respectively and when moving baskets are removed after segment 15 th finished, calculate the following values:

1) Accumulative construction value (consisting of temporary load during construction, weight of structures, secondary load, pre-stress, displacement caused by stay force) can be calculated through the model, and then reverse it. The camber is as shown in the Figure 3:

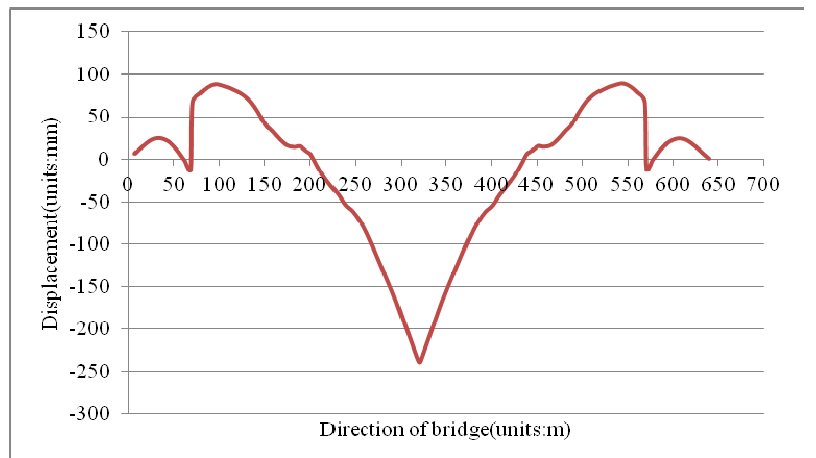

Figure 3. In the first case, cumulative construction camber

2) Combining quadratic parabola distribution method and empirical values, camber of shrinkage and creep is as below: 


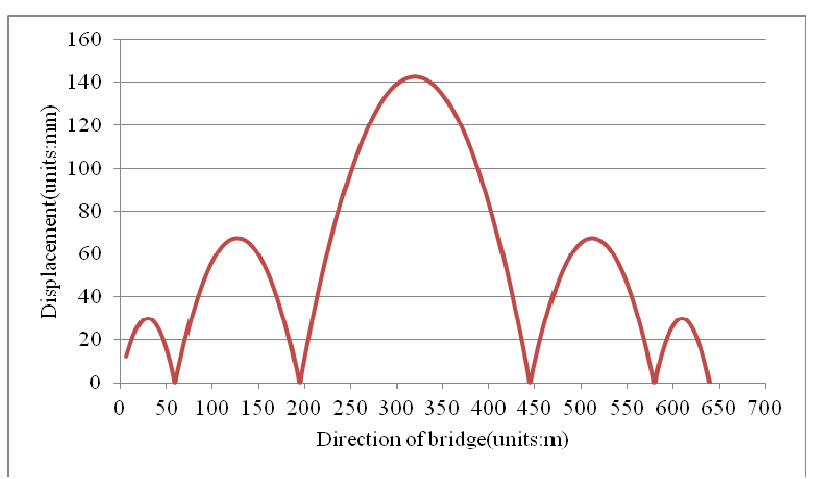

Figure 4. In the first case, shrinkage and creep camber

3) Camber of $1 / 2$ live load which is the reverse value of displacement from the model:

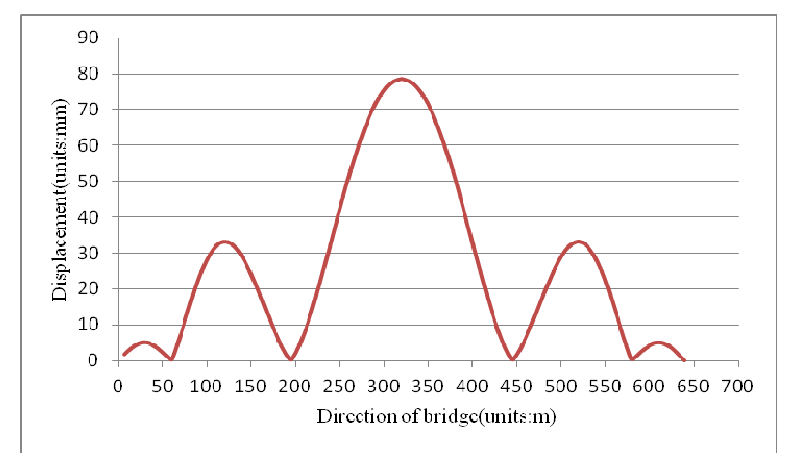

Figure 5. In the first case, $1 / 2$ live load camber

(b) According to the second situation, weights of side span and central span are applied together, and moving hanging baskets are then removed after closure of central span.

1) Accumulative construction value (consisting of temporary load during construction, weight of structures, secondary load, pre-stress, displacement caused by stay force) can be calculated through the model, and then reverse it. The camber is as shown in the Figure 6:

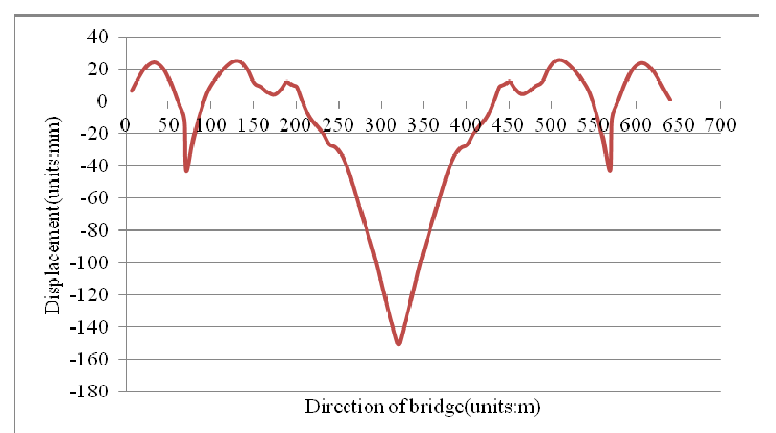

Figure 6. In the second case, cumulative construction camber

Comparing the first situation with the second situation, because of the differences of the sequences of applying weight and removing baskets, cambers after bridges being built is same in two situations, namely, the camber of shrinkage and creep, and camber of 1/2 live load in the second situation is the same as those in the first one.

(c) When construction processes change, the contrasting of cambers in the two situations is:

From the design formula of camber:

$$
f=f_{i}+f_{c}
$$




$$
f_{i}=\sum f_{1 i}+\sum f_{2 i}+f_{3 i}+f_{4 i}+f_{5 i}+f_{6 i}+f_{7 i}+f_{8 i}
$$

We know the total camber is the sum of cambers during construction and cambers after bridges being built, just as the following figure of contrasting between cambers under two situations:

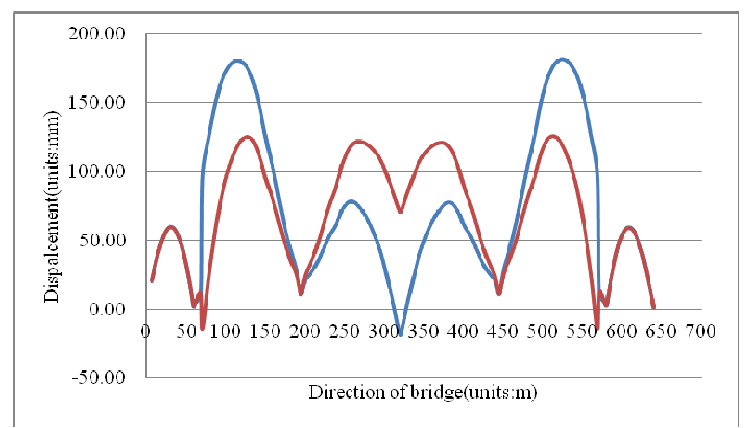

Figure 7. Contrasting of cambers caused by two construction processes

According to the contrasting of several segments from the previous results ( $\mathrm{p} 4 \mathrm{p} 5$ stands for the number of piers):

Table 2. Contrasting of several phrases between two construction processes (unit: $\mathrm{mm}$ )

\begin{tabular}{|c|c|c|c|c|c|c|c|c|}
\hline & $\begin{array}{c}\text { p4 side } \\
\text { span Block } \\
15\end{array}$ & $\begin{array}{c}\text { p4 side } \\
\text { span Block } \\
5\end{array}$ & $\begin{array}{c}\text { p4 central } \\
\text { span Block } \\
5\end{array}$ & $\begin{array}{c}\text { p4 central } \\
\text { span Block } \\
15\end{array}$ & $\begin{array}{c}\text { p5 central } \\
\text { span Block } \\
15\end{array}$ & $\begin{array}{c}\text { p5 central } \\
\text { span Block } \\
5\end{array}$ & $\begin{array}{l}\text { p5 side } \\
\text { span } \\
\text { Block } 5\end{array}$ & $\begin{array}{c}\text { p5 side } \\
\text { span } \\
\text { Block } 15\end{array}$ \\
\hline $\begin{array}{l}\text { The first } \\
\text { construction } \\
\text { scheme }\end{array}$ & 95.4 & 124 & 60.9 & -16.1 & -18.2 & 60.4 & 124.7 & 96.3 \\
\hline $\begin{array}{l}\text { The first } \\
\text { construction } \\
\text { scheme }\end{array}$ & -14.8 & 94.5 & 88.4 & 72 & 70.6 & 88.1 & 95 & -14.6 \\
\hline $\begin{array}{l}\text { Difference of twc } \\
\text { kinds of } \\
\text { construction } \\
\text { schemes }\end{array}$ & -110.2 & -29.5 & 27.5 & 88.1 & 88.7 & 27.7 & -29.7 & -110.9 \\
\hline
\end{tabular}

According to the analysis, changes of construction processes have a great impact on camber installation for long-span railway cable-stayed bridges through the effect of accumulative phrase on cambers. Therefore, before alignment control, we should ascertain the key phrase, that is, appropriate alignment control.

\section{Conclusion}

(1) Different construction processes have a great impact on installation of appropriate cambers of long-span railway cable-stayed bridges. Therefore, when designing, reasonable construction states should be confirmed based on construction processes.

(2) During construction, internal forces and alignment control should be intensified. To obtain the objective, warning system about construction processes can be established.

(3) As shrinkage and creeping have a great and complex effect on the alignment control of long-span railway cable-stayed bridges, the regularity can be found out by experiments that shrinkage and creeping affect long-span railway cable-stayed bridges.

(4) Considering the differences between long-span railway cable-stayed bridges and highway cable-stayed bridges, more researches should be carried out about dynamic property's impact on installation of appropriate cambers. 


\section{References}

Curran, P., \& Tilly, G. (1999). Design and monitoring of the Flintshire Bridge, UK. Structural Engineering International, 3, 225-228. http://dx.doi.org/10.2749/101686699780481970

Ding, W., Lu, J., Meng, S., \& Liu, Z. (2004). The research on prediction model of concrete shrinkage and creep. Bridge Construction, 2004(6), 13-16.

Fan, L., \& Du, G. (1992). Backward analysis force optimization and nonlinear ideal cable-stayed bridge. Journal of Chongqing Jiaotong University.

Ge, Y. (2003). Section analysis and construction control of bridge. Beijing: China Communications Press.

Housner, G. W., Bergman, L. A., Caughey, T. K., Chassiakos, A. G., Claus, R. O., Masri, S. F., .., Yao, J. T. P. (1997). Structural control: Past, present, and future. Journal of Engineering Mechanics, 123(9), 897-971. http://dx.doi.org/10.1061/(ASCE)0733-9399(1997)123:9(897)

Lang, X. (2006). Research on metod of geometry control during cantilever erection of PC cable-stayed bridges. Master Dissertation of Sounthwest Jiaotong University.

Li, G. (2010). Study on construction of PC cable-stayed bridge control of main beam. Master Dissertation of Chang' an University.

Tan, H., \& Zhang, J. (2008). Cable prestress and alignment double control during construction of large-span cable-stayed bridges. Joumal of Hehai University (Natural Sciences).

Wang, P., Tang, T., \& Zheng, H. (2004). Analysis of cable-stayed bridges during construction by cantilever methods. Computers \& Structures. http://dx.doi.org/10.1016/j.compstruc.2003.11.003

Xiang, H. (2001). Advanced theory of bridge structures. Beijing: China Communications Press.

Xiao, R. (1992). Structure for the influence matrix method of internal force displacement adjustment calculation. Computation and application of structural mechanics.

Xiao, R. (1996). Study on design theory and method of determining reasonable state of long-span bridge structure. Doctoral dissertation of Tongji University.

$\mathrm{Xu}$, J. (2000). Construction control of long-span bridges. Beijing: China Communications Press.

Zhang, J. (2004). No back-stays \& inclined pylon cable-stayed bridge static performance and Research on the reasonable finished dead state. Master Dissertation 1of Changsha University of Science and Technology.

\section{Copyrights}

Copyright for this article is retained by the author(s), with first publication rights granted to the journal.

This is an open-access article distributed under the terms and conditions of the Creative Commons Attribution license (http://creativecommons.org/licenses/by/3.0/). 